The following Paper was read :-

\title{
On Excavations on the Site of the New Law Courts.
}

By Wilfrid H. IItdegetor, Esq., M.A., F.G.S., F.C.S., and F. G. Hilton Price, Esq., F.R.G.S., M.A.I.

It is well known to most of the inhabitants of London that the Government have decided to erect the long-talked-about Courts of Justice in the Strand, upon what is called the Carey Street site. This site, occupying an area of seven acres, was cleared of its houses about three years ago, when nearly 4000 people were turned out.

It is recorded in the "Memorials of Temple Bar," by Mr. T. C. Noble, that early in the 14 th century the Strand ontside Temple Bar was nothing better than a marsh, and that two bridges had in later times been thrown across two rivulets, which ran from the higher ground to the Thames. One of these bridges, consisting of stone, and 11 feet in length, was found covered up by rubbish to the eastward of St. Clement's Church, in 1802. This was possibly the very bridge mentioned in the reign of Edward III., as built by the Templars by the "King's command."

Since the "Rookery" on this site has been swept away, extensive excavations have been made for building the foundations of these Law Courts. We have been permitted, from time to time, to visit these excarations, through the courtesy of Mr. Lett, the foreman to the contractors, who, in conjunction with Mr. Collins, the Clerk of the Works, has rendered us every facility for seeing anything of interest that has been discovered.

The area excarated is pretty nearly square, being about $500 \mathrm{ft}$. in length on the Strand or S.S.E. face, and about the same on the Bell Yard, or E.N.E. face. To simplify matters, the Strand face will always be described as $\mathrm{S}$., the other sides and angles accordingly. The floor of the excaration at the Temple Bar corner is about $33 \mathrm{ft}$. above the Ordnance datum line, but trial shafts have been sunk as low as $28 \mathrm{ft}$. above the datum line, in all cases terminating in the London Clay. It is to be regretted that a more accurate record of the various layers passed throngh on sinking these shafts has not been preserved. Had the measurements been geologically reliable, very interesting general sections each way might have been constructed. 
Those who have been engaged on the work of excavation recognise four varieties of beds, which we may describe as-

a. Brick Rubish and Made Sorl.-This consists largely of the various materials of previous houses decaying, and being built over during a long period of time. The many interesting remains of glass, pottery, and other relics of man found in this division, belong rather to the domain of the archæologist than to that of the geologist. There has, however, been found the upper portion of a human skull, which, as it lay at the very bottom of a bed of mould projecting deeply into the gravels, may fairly be entitled to some notice in this paper. It may be as well here to draw attention to the extreme irregularity in the line of junction between the brick rubbish (including under that name also the mould beds and other shifted materials), and the underlying gravels.

Many an old foundation may be seen projecting like a promontory into the subjacent sandy gravels, and where these thin out into the London Clay itself. The numerous old wells also tend to confusion in this respect. Such accidental thickening of surface material may be the cause of the remarkable variations in the depths assigned to made earth, given in the various borings executed in and about London. That at the Bank of England, for instance, where $22 \mathrm{ft}$. of made earth and only $4 \mathrm{ft}$. of gravel are stated to lie between the surface and the London Clay.

b. Gravels and SAND8.-The gravels are of considerable utility to the contractor, as they are used in making the concrete which is to form the foundation of the future Law Courts, and for this purpose are sifted from the sands, with which they are largely mingled. Such a very extensive sifting as these have undergone throughout the entire area, would inevitably lead to the discovery of most of the organic remains therein contained. It will be seen, however, subsequently, that very little has been found of this nature. A more detailed notice of these gravels and sands, as regards their compusition and mode of occurrence, will be given when we come to consider the special sections.

c. The so-called RED LOAM oR WET CLAY.-In tho majority of cases the above-mentioned beds terminate very abruptly, upon a woderately uneven surface of a fox-coloured clay, which itself tones down, in some places gradually, in others with an appearance of demarcation, into the regular blue London Clay. It is, in fact, the London Clay in situ, but partially affected by oxidation, and infiltra- 
tion from above. The nature of these changes, which extend also to the included septaria, are of considerable interest. On comparing, for instance, dried and partially powdered specimens of the red and blue clays, we find in both a most remarkable freedom from grit; the particles are of excessive fineness, and those which are larger than others seem to be merely cakes of the very finest powder agglutinated by pressure. In the case of the red clay, these particles appear to have a reddish smear, the colour of which is principally due to ferric oxide.

$c^{\prime}$ The fourth variety of material observed in these excarations is the regular Blue London CLAY, with its large septaria, Teredobored wood, pyrites, Nautilus, Fusus, \&c., forming the basis of the whole. A more detailed mention of the fossils found will be attempted subsequently.

In the blue clay, extremely minute fragments of iron pyrites are distinctly noticeable with a lens in considerable abundance, and tend, in addition to the grey colour of the general substance, to give that dark hue to the unaltered portions of London Clay. The indications of ferrous oxide in the blue clay are very strong, whilst in the red clay ferric oxide wonld appear to predominate. The actual amount of metallic iron in air-dried specimens of the two clays is about $4 \frac{1}{4}$ per cent. in the blue clay, and 5 per cent. in the red clay. No iron pyrites conld be made out in the red clay, and as no sulphuric acid is traceable after fusion, it may be pretty confidently stated that none exists in the specimens examined. Carbonates of lime and magnesia, in almost dolomitic proportions, exist to some extent in the blue clay, much less so in the red. The amount of phosphoric acid in the blue clay is considerable, in the red it has not been determined. The principal changes which the London Clay, in contact with the porous gravels, undergoes, may thus be summed up. Conversion of ferrous oxide, which exists partly, perhaps, as carbonate, but principally as one of the basic elements of the silicate comprising the bulk of the mass, into ferric oxide, oxidation of the pyrites, and removal, to a considerable extent, of the resulting sulphuric acid, and diminution of the carbonates of lime and magnesia.

The septaria in the red clay are equally attacked. Instead of the pale-grey compact cement-stone, we have, indeed, the lenticular form it usually assumes, but the substance is a yellow, greasy 


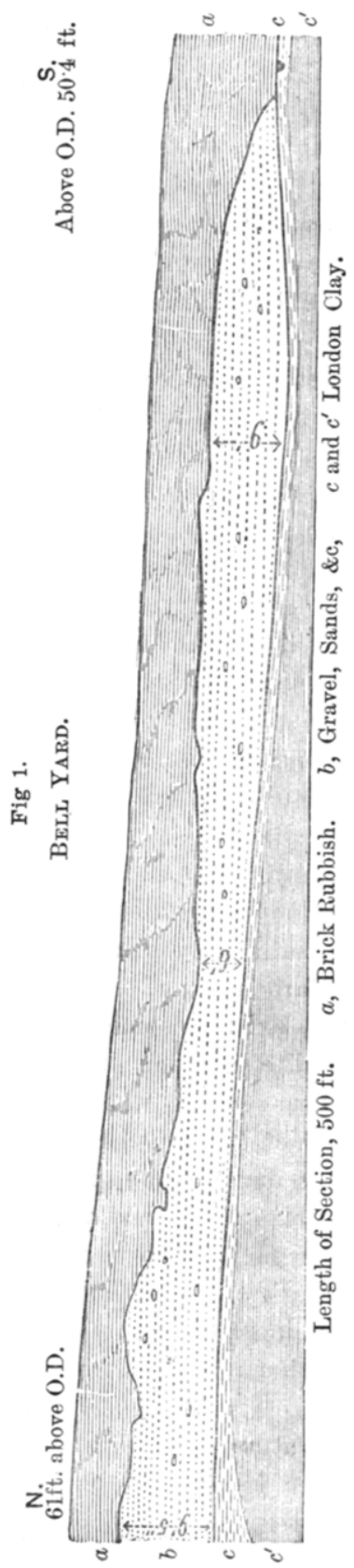

mass, more or less crumbly, according to the change undergone. A specimen compared with one taken from the blue clay immediately below gives 46 per cent. of matter insoluble in acid, as against 23 per cent. in the specimen from the blue clay, showing a loss of upwards of 20 per cent. of its carbonates. Again, the iron, which is pretty plentiful in the ordinary cement-stone of the London Clay (the concretion being analogous to the wellknown clay ironstones of other districts), exists almost entirely in the dyad state, except at the edges; whereas, in the decomposing form occurring in the red clay it has passed into the triad state, and some of it into that form of ferric oxide which is insoluble in hydrochloric acid.

\section{General Sections.}

Having thus briefly noticed the four varieties of beds bere occurring, the two last being simply different conditions of the London Clay, we may now advert to their respective thickness and position with regard to each other.

Fig. 1 may be taken to represent a section about 500 feet long, from N. to S., parallel to and in the vicinity of Bell Yard, that is to say, down hill, and at right angles to the course of the river. Here the original surface slopes from 61 feet above Ordnance datum line to 50.4 feet above it. The accumulation. of rubbish at the back of Temple Bar unduly thickens the amount of made earth hereabouts. This circumstance, viz., the great thickness of surface accumulation, to a certain extent interferes with comparisons afterwards taken 
at other points of the Thames Valley. It especially affects the S.E. corner of our area. Along this section generally the thickness of surface material is from 6 to 7 feet.

It will be observed that the gravels and sands, according to these measurements (which are partly derived from the test-hole borings) have a thickness of 9.5 feet in the N.E. corner, and after maintaining a general thickness of about $7 \cdot 5$ feet, except for a very short distance, thicken out again to 9 feet further down the hill (a thickness of 11 feet is attained a little to the west of the line of section) and then, after thinring away to 2 feet as we approach the Strand, disappear rapidly close to Temple Bar, where the Brick Rublish rests directly on the London Clay. This would also appear to be the case all along the lower or Strand face of the excaration, a little gravel in occasional hollows of the clay alone being noticeable.

The curve of London Clay surface here exhibited is, as regards the S. part, obtained from actual observation, to be shown in a special section presently. The northern portion of it is assumed from test-hole measurements. The most remarkable circumstance with regard to it is the fact of the northward slope of the portion nearest the Strund. If this is continued much to the right of our section there must be a sort of outcrop of the London Clay along the line of the Strand, which is not indicated eren in the last edition of Mylne's most excellent map. This may perhaps account for what we know of the condition of the Strand in the $16 \mathrm{th}$ century, where the road is described as being "full of pits and sloughs, very perilous and noisome" to the passers-by. That the clay forms the original surface here without any covering of gravel, may be inferred from the traces of tree roots which are still obvious at considerable depths. The name Holywell street likewise is suggestive of springs in these parts, which rather points to a similar conclusion.

Bearing these facts in mind, and coupling the northward slope of the clay with the rapid disappearance of the gravels of the Law Courts area, it would seem that there is a regular bench of London Clay, having a moderate northward slope, interposed between the gravels of this area, and those of the declivity immediately above the Thames. The height at which these gravels disappear may be stated to be about 35 feet above Ordnance 
latum line, as far as we can judge. If we add six feet as the mean of surface accumulation, this would bring the northern or upper margin of the clay bench to 41 feet above Ordnance datum, reckoning from the surfuce. It is worth observing, also, that in the northern portion of this section there is a point where the surface of the London Clay falls away again to the north, and, although a mean rise of 8.3 feet is established in the 500 feet, there are two instances where the slope is the reverse way for a considerable distance. This peculiarity will be again alluded to in describing the special sections.

Referring again to Fig. 1, the dotted line following the curve of the London Clay indicates the extent of the red or altered clay on the $\mathrm{S}$. as observed, on the $\mathrm{N}$. as conjectured. The vertical scale is, of course, very much exaggerated.

A section from E. to W. parallel to the Strand would show a great roll or swelling which the London Clay makes through the middle of the area, attenuating the gravel on either side, and almost cutting it out altogether, even as high up as the office of the Clerk of the Works, and within 100 feet of Carey Street. North and south sections in the vicinity of the axis of this swelling would show a very great diminution in the thickness of the ballast beds.

Close to the Strand this is not observed, owing to the entire absence of the gravels, but a section parallel to this and about 150 feet further northwards (see Fig. 2) shows the result of this roll on the ballast beds.

Fig. 2.

W. Conjectured.

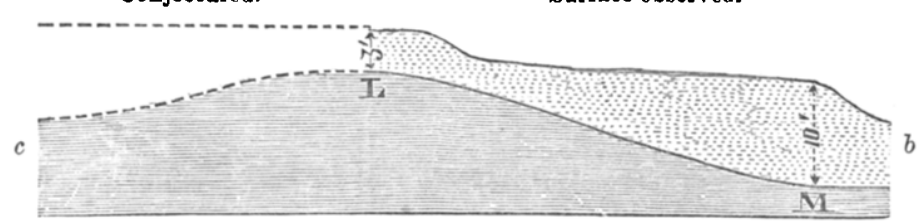

Length of section, 150 feet. $b$ Gravels and Sands. $c$ Loodon Clay.

Here, between $L$ and $M$, we have an extremely smooth slope of

* NowE.-The 41 feet line represents the northern margin of the clay bench, as it wonld have to be indicated on a map of the surface, though actually 6 feet lower. The position and peculiarities of this bench are noteworthy, affording some insight into the relations of these gravels. Thus the Law Courts sectinns, though repulsire to the pure palontologist, from the poverty and doub: ful charscter of included remains (quâ gravels), may be of some service in other respects. 


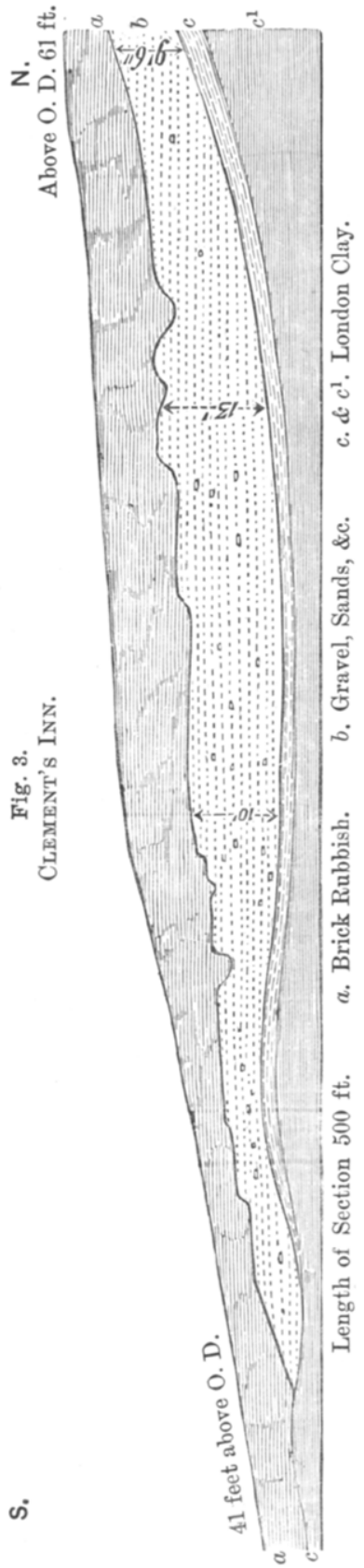

London Clay, which in one part has an inclination towards the S.E. of 1 in 11 , or rather more than 5 degrees, with 10 feet of ballast at $M$ and about 3 feet at L. Allusion will be made, subsequently, to certain peculiarities noticed in the gravels and sands of the deeper part of this section.

This swolling divided the works into two distinct systems of drainage; that towards the $\mathrm{E}$. having its lowest level, as exhibited in Section No. 1, at about 100 feet from the southern extremity (this point is marked $x$ in Fig. 4); that towards the $W$. probably at the S.W. corner of the area. The vertical scale is here also very much exaggerated.

Fig. 3 may be taken to represent a section parallel to the first, and at the opposite extremity of the area. The original surface slope is here more considerable; but here, also, we have the gravels and sands thinming out to a vanishing point, and the surface of the London Clay sunk as low as 31.5 feet above Ordnance datum line at the S.W. corner; in fact, so low that the basement is concreted on Brick Rubbish for a few yards at this particular spot. The sandy gravels further up the hill attain a depth of 13 feet, if the test-hole measurements are to be relied upon. They are more sandy on this side of the area. Not far from this line of section, and about 3 feet under 
the sands, were discovered the horns of Bos longifrons and Capra hircus exhibited this evening."

\section{Specrat, Sections.}

Before attempting to institute any comparison between the beds exposed in this area, and those which rest on the London Clay (as ascertained from borings and other works), in various districts of the metropolis, it will be convenient to describe some special sections taken from actual observation during the progress of the works. These have been selected partly to shew the relations of the beds to each other in a given place, partly to exemplify the nature and mode of occurrence of the sandy gruvels as evinced in certain spots, and partly to illustrate any local peculiarities worthy of notice.

N.

Fig. 4.

BELL YARD.

s.

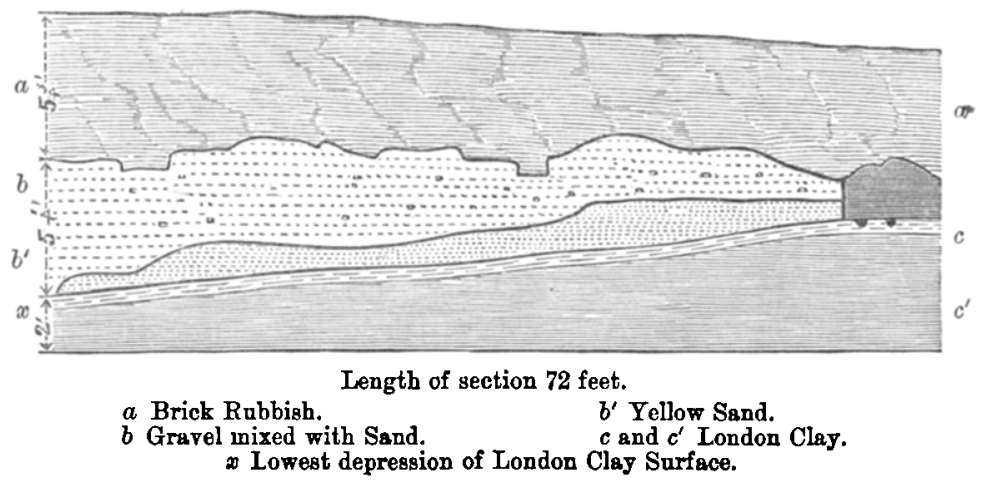

Fig. 4 is a section viewed from the floor of the excaration in the S.E. corner, and not far from Temple Bar. A portion of the Brick Rubbish on the surface may have been previously removed; but this is an exact representation of the appearance as seen from below. The upper surface of the gravel is, to a certain extent, indented by foundations, but otherwise wholly undisturbed. The length exhibited is 72 feet wut of the 500 feet shown in Fig. 1 (the Bell Yard General Section).

" "Bos longifrons and Capra hircus." These are comparatively modern forms, and, according to Mr. Boyn Dankins, not admissible into the toue Post Glacial Fauna ("British Post Glacial Mammals," Quar. Jourv. Grol. Soc., vol. xxr., p. 192). The latter specis $\mathrm{Mr}$. Dan king considers to lave beten brought by man during the Pre-historic Epocb. The fact that these reming were found rather high in the ballast beds, points to the possibility of their Laving fallen through from some surface deposit of an age long subsequent to that of the gravels themselves. 
It will be observed that in less than 70 feet the Sandy Gravels thin out from 5.25 feet to 2 feet, and then suddenly disappear. The point of their actual disappearance is concealed by a slip of brick rubbish, but a little further to the right this is seen to rest directly on the London Clay, with here and there what looks like a pocket or streak of gravel. It is always doubtful, however, so near the boundary line of surface accumulations, whether these pockets are natural or artificial. That they are natural is, however, highly probable, and that they present an important analogy with more recent phenomena will presently be shown. As before observed, the London Clay is cut away so as to slope from the line of the Strand, i. e., away from the Thames. In 72 feet the surface falls from 4.5 feet above the floor to 2 feet above it. Northwards from the point $x$ it begins to rise again. The gravels here observed seem to be an irregular accumulation of large and small subangular flints, mixed with some flint pebbles, and with reddishyellow sands. In places a partial sorting of the materials prevails, and towards the bottom there is a distinct layer of fine yellow sand, which intervenes between the red clay and the other gravels; this seems to vanish towards the point $x$.

A more general, and, perhaps, more typical representation of the mode of occurrence of these sandy gravels is attempted in Fig. 5,

Fig. 5.

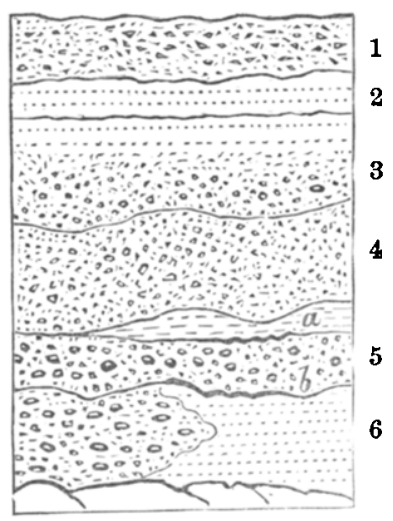
which is a section of about $7 \frac{1}{2}$ feet of these "Ballast Beds," as they are called by the workmen. It occurs towards the N.E. corner, and, therefore, on the E., or Bell Yard side of the great swelling of the London Clay which runs through the area.

It must not be supposed that the actual demarcations are quite so strongly contrasted as here indicated; the changes from sand to gravel and from gravelly sand to sandy gravel being in some cases gradual, in others pretty sharp.

No. 1, then, represents layers consisting mostly of small fractured flints, interspersed with reddish sand.

No. 2 represents a mass of greenish sand almost entirely free from flints. 
No. 3 represents a thicker mass of yellowish sand, becoming charged with flint gravel in its lower parts.

No. 4 represents a very pell-mell mixture of sandy gravels, which in the lower portions are remarkable as being smeared with a brick-red, sticky loam, forming a layer 2 or 3 inches in thickness.

a. Partially intercalated between these and the next beds, is a line of black sand, occurring as here shown. It is similar to others found occasionally in different parts of the ballast, as first pointed out to us by Captain Marshall Hall. The black colour is due to one of the higher oxides of manganese.

No. 5 represents a bed containing larger flints than usual; several of them oval and well polished, regular pebbles, in fact, such as occur in the Lower London Tertiaries, which are brought up to the surface in the N.W. corner of Kent, but must lie 150 feet below us here.

b. Here occurs a gravelly pocket, the individual stones of which are deeply smeared with black oxide of manganese. Immediately below the level of this

No. 6, a thick bed of greenish yellow sand, is seen to abnt upon a bed consisting mostly of tolerably large sized flints and flint pebbles.

A few words as to the composition of the materials of these evervarying Ballast Beds may not be out of place.

Mr. Prestwich has ohserved ("The Ground Beneath Us," Van Voorst, 1857, page 10, et seq.) that the gravels on Clapham Common, for instance, "consist of angular flints with their edges slightly worn, and of flint pebbles perfectly rounded, imbedded in a coarse siliceous sand, mixed with a small proportion of clay, and the whole coloured by the oxides of iron." He further alludes to the presence of chert, of a few large pebbles of whitish quartzite, of reddish sandstone, and of slate rocks. The flint pebbles are no doubt derived from the Lower Focene beds. There occur, moreover, in these Ballast Beds, masses of a hard white sandstone, so compact as almost to resemble quartzite, one mass weighing probably not less than $3 \mathrm{cwt}$. We presume that these are "greywethers" or "sarsen stones," which Mr. Whitaker tells us (Memoir on Sheet 7, p. 72) are frequently found over the London Clay country, and therefore may be expected to occur in gravels resting on that clay, without having recourse to any extra mechanical agency to account 
for their appearance in company with the smaller flint masses amongst which they are found. They usually exhibit, when found in this area, an irregularly angular shape, with the angles remarkably smoothed, very much like a block of rock-salt that has been licked by sheep. Mr. Whitaker is disposed to believe in their being derived from the Bagshot Sands, which would originally pass about 300 feet above the plane of this excaration. These masses must not be confounded with the quartzite pebbles which occur sparingly throughout the gravels.

As regards the finer materials, or sands, they vary in colour from brownish-red to reddish-yellow, yellowish-green and greenish-grey, and in size from extremely fine grains to a coarsish grit, the latter predominating. In the coarser sands the proportion of flint fragments increases, every gradation being passed through till we get to a sandy flint gravel. But whatever their colour, the ordinary sands consist of about 90 per cent. of rounded or subangular quartzose grains, a large proportion clear and translucent as rockcrystal, others of a semi-opaque amber-like appearance, with a few jaspery and calcedonic varieties. About 8 per cent. may be assigned to dark green bodies, occurring in oval, rounded, and reniform grains; and also, if it be really the same substance, in more or less angular fragments. These may be simply hydrous silicates of iron, or they may be fragments of a more complex pyroxenic mineral. In either case they may have been derired from the Greensand.

The general composition of the sands being similar, to what cause are we then to attribute their very considerable varieties of colour?

In the case of the black sands and gravels, this is most undoubtedly due to a black oxide of manganese, which is sufficiently plentiful as immediately to decompose hydrochloric acid in the cold with evolution of chlorine. It merely invests the grains and pebbles, being sometimes associated with a very fine clayey matter, and also more or less with ferric oxide. It is not clear whether the latter enters into composition with it as an ingredient of its mineral constitution, or is merely mixed with it. In cutting back the ballast further up the hill, these black-stained sands and gravels may be traced for a little distance, in some places thickening out to a pocket, in others thinning to a mere string. The origin and cause of this deposit of the manganese is worthy of investigation. 
As regards its origin, it has been suggested that it may possibly have proceeded from artificial causes, such as old bleaching-works; the occurrence, however, is too frequent over the area for this to have been the case. Moreover, when there is a black coloration of the sands and gravels due to artificial canses, the colouring matter is much more likely to be black sulphide of iron. There was a good illustration of this occurring in the very thick Ballast Beds shown in section 2. These beds had been dug into to a. certain extent previously. In one part, below a spot which the workmen declared to have been a cesspool, there was a great blackening of the sands, in appearance somewhat similar to the black sands just described, but the black colour was more diffused. Though so similar outwardly, the blackening of the ballast was, in this case, due neither to manganese nor to carbonaceous matter, but to Protosulphide of Iron.*

Again, besides the bleaching-works theory, it has been suggested that these deposits of manganese are due to some sewage infiltration. We do not, however, see any reason to suppose that this is so. In all probability where there is a blackening from artificial impurities, it will generally be found due to this black sulphide of iron. This is the stuff that one sees in the vicinity of gas pipes; and singularly enough the modern beach of the Thames at low water, where there is a delivery of sewage, is largely charged with it.

A close investigation into the properties of this substance, which is also an artificial product of the laboratory, might throw some light upon the production and segregation of pyrites (bisulphide of iron) $t$ in the various formations.

We may here observe that the entire absence of any noticeable

- That it exists as a protosulphide (the black bydrate, thougb probably of variable composition), we infer from the readipess with which it yields sulphuretted hydrogen to hydrochloric acid. The more soluble organio matters from this cesspool had passed through the porous sands during the period of its use, contributing their poisons to the waters, which percolated near the surface of the upholding clay. Clear and sparkling the liquid might appear when drawn from adjoining wells, but it doubtless proved a fatal draught to many a one who drank it. Besides these cesspools the fat churchyard of St. Clement Danes would further contribute to enrich the quality of the water in the lower wells. As an exemplification of this we saw two coffins drawn out of the bottom of a well adjoining this churchyard on the nortb side-just outside the Lew Courts area. They must bave been there for several years. In all probability the people who inhabited the honse over it, drank of this water, charged as it must have been with organic matter of the most deadly description!

+ Sulphide of Iron, Fes., black, soluble in bydrochloric acid.

Bisulphide of Iron, FeSz, brass yellow, crystalline, insoluble in cold hydrochloric acid.

Magnetic sulphide, $\mathrm{Fe}^{7 \mathrm{~S} 8}$, of ten nickeliferous. 
quantity of carbonaceous matter in the undisturbed portions of the Ballast Beds is remarkable.

Reverting to the manganese, certain planes of bediling are occasionally colonred for considerable distances, generally rather low down in the Ballast Series, and often underlying unusually ferruginous beds of it. The source of the manganese is either the London Clay itself, or else the dark greer mineral before alluded to. As to the cause or mode of deposit, this we must look for in the perpetual running of water through the porous beds. Many streams were cut through in the conrse of the excavations, and it is probable that these streams occasionally changed their courses, widening out at times so as to pervade a bedding plane for considerable distances, and then perhaps escaping through a slight fissure into a more defined channel. 'These waters are charged at times with manganous and ferrous carbonates, of which the latter is more readily deposited, as a peroxide; hence the separation of the two.

There can be little doubt that to the percolation of water this phenomenon is due, and this may explain the fact of these black beds being rather more frequently met with in the lower portions of the Ballast. When the excavations commenced the lower portions were extremely full of water; these manganese beds appear to have been courses, where the water came "dribbling like," as we were told by one of the watchmen. A large catchwater drain is run along the whole of the north side of the area to intercept the subterranean streams coming from the unexcavated gravels to the northward. One of the effects of this has been to dry up the Lincoln's Inn pump.

Returning now to the subject of the general colouration of the sands. This is undoubtedly due to the surface coating or spotting of the quartzose grains with ferric oxide in different states of hydration. It is observable that the yellower sorts are generally pretty clean, whilst those which have an ochreous smear upon them are frequently of a dirty brownish red. The greenish varieties have, in addition to the usual gellowish stain, certain dark green specks upon the grains of quartz. These appear like comminuted fragments of the above-mentioned green mineral, which slso obtains in rather greater quantities in these varieties of sands.

We must refer again to the effect of carbonated waters permeating the loosely packed formation. These dissolve out salts of iron, 
either from the surface of the London Clay at higher levels, or from the green mineral before mentioned. Air, at the same time, pervades the entire mass, oxygen is absorbed, insoluble ferric oxide is deposited, and the carbonic acid so liberated is ready for fresh work, perhaps to dissolve out some other matter in the formation. The reds, yellows, and browns, are probably due to different states of hydration of the ferric oxide. How these different states arise is too purely a chemical question to discuss here.

It may be noticed, in concluding this part of the subject, that the general appearance and shape of the grains of sand, especially of the finer varieties, is pretty much that of modern sea-sand, such as night occur on the beach at Brighton. The difference lies in the exterior coating. This circumstance, however, throws no light upon the mode of deposition of these beds, because whether fluviatile or marine, their contents ( $q u \hat{d}$ sand) must be largely derived from the neighbouring Tertiaries, which themselves were derived in part from the also neighbouring Greensands. Beyond this point we need not pursue the investigation of their origin. Every time they changed their beds for a fresh resting place, these little grains of silica would be apt to have something taken off the angles, so that those which are roundest may perhaps lay claim to the most chequered existence. From what parent rock they were torn in the first instance, and how long ago, is a question which may never be solved.

Fig. 6.

S.

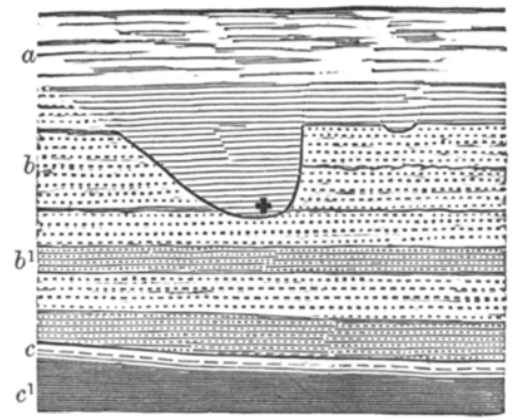

a. Brick Rubbish and Made Earth.

$b$. Gravel. $b^{1}$. Sands.

c. \& $c^{1}$. London Clay.

Fig. 6 is intended to illustrate a section occurring in the western part of our area. The excavation at this spot is $22 \mathrm{ft}$., and shows 
upon the surface several feet of brick rubbish, \&c., resting towards the $\mathrm{N}$. end upon gravel and gravelly sands, and. on the S. upon vegetable mould, or made earth. This section plainly indicates that at some not very distant period there was a gravel pit here, though probably not later than the 16 th century.

The gravel has been removed in one part to a depth of $12 \mathrm{ft}$., the excavation inclining towards the $\mathrm{S}$. until it thins out at the surface. When it was found necessary to level this ground (probably for building purposes), the void caused by the removal of the gravel was filled up with made earth, which contains the bones of recent animals, partially decayed, and bullocks' horns; these probably were the refuse of butchers' shops and kitchens. Amongst other things many shells of the common cockle and oyster were observed.

At the bottom of this pit, $12 \mathrm{ft}$. from the surface (marked $\mathrm{X}$ in the Fig.) was found resting upon the gravel the calvaria of a human skull. This has been examined by Dr. Carter Blake, F.G.S., but unfortunately, owing to its fragmentary condition, he was precluded from taking any accurate measurements; so could simply come to the conclusion that it must have belonged to a large and extremely dolichocephalic individual of low type. How this human bone could have come into the place where it was found, we are at a loss to conceive, as no other human remains have been discovered, with the exception of a few skeletons which were found just below the surface in the brick rubbish. The owners of these bones, we conjecture, may have met with violent deaths, as this spot has been celebrated for centuries for the lawlessness of its inhabitants. There is no doubt that this calvaria is of considerable antiquity, as the animal matter is almost entirely absent from it.

The gravels immediately underneath the spot where this bone rested are sandy, and intermixed with subangular flints, with here and there a pebble, similar to those already described as occurring npon the E. side, without, however, just here exhibiting any stains of manganese. At a distance of about $1 \check{5}$ feet eastward from the sections described, and lying about 3 feet from the top of the Ballast Beds (here very sandy), were found the horn cores of Bos longifrons and Capra agragus (C. hircus, Linn).

In the sandy gravels at the N.W. corner of the excavation, and at $\mathbf{a}$ depth of about 7 feet from the surface, another horn core of a Bos was found. This specimen, which, unfortunately, is broken in to two pieces, was shown to Mr. Davies, of the British Museum, 
who gave it as his opinion that it was the horn core of a cow, or of a young individual of Bos primigenius.

At a distance of a few yards from where this interesting fragment was discovered the jaw and a part of the humerus of a horse were found. These remains were also shown to Mr. Davies, who saw no reason why they should not be assigned to the Equus caballus fossilis, taking into consideration the position in which they were discovered.

The Ballast Beds (where undisturbed) in the vicinity of section 6 are of considerable thickness; here we have 4 feet of red gravelly sand, with a thin stratum of greenish sand, mixed with pebbles, running through it. Below this a layer of very fine yellow sand, containing minute black grains, reposing upon sandy gravels, with large flint pebbles interspersed. Then another stratum of fine yellow sand is seen, which gradually becomes coarser. These rest upon the foxy-coloured clay, of which, however, a very little is exposed in this particular section.

A reference to the generalised section (Fig. 3) will show how rapidly the gravels thin out a little below this towards the corner near St. Clement Danes Church.

Fig. 7.
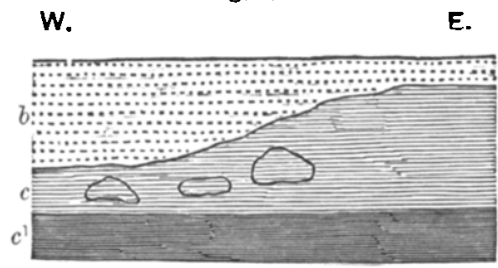

b. Gravels, sc.

c. Reddened London Clay.

$c^{1}$. Blue London Clay.

Fig. 7 represents a section which occurred towards the N.E. of the area, and not far from Carey Street. At this spot the whole of the brick rubbish had been removed when this sketch was taken. $b$, then, represents the Ballast Beds, here composed of red sandy gravels and gravelly sand, containing rolled fint pelbbles; in places, also, large angular flints. These beds had a thickness of 8 feet at the W. end, and rested upon the reddish clay (altered London Clay), in which septaria were observed to occur, some of which, when broken through, were found to contain Nucula Bowerbankii and a species of Voluta. The red clay at this end of the 
section was only two feet in thickness; it gradually thickened out towards the $\mathrm{E}$. at a gentle inclination, where it reached its highest point, which was from $3 \frac{1}{2}$ feet to 4 feet. Having reached this altitude, it seemed to thin out towards the N.E., and then to disappear. Immediately below this bank of red clay was the blue London Clay. The peculiarity of this section is the existence of the swell or roll of reddish clay lying between the gravels and the blue clay. Fig. 7 is intended to represent the northern end of this 6well, which terminated abruptly at this spot. It has been observed to extend right through the area from the Strand in a N.N.E. direction, thus forming a sort of watershed for the drainage of the gravels, as already indicated in Fig. 2.

Had this section been made 3 feet further back, i. e., nearer to Carey Street, this roll of reddish clay would not have been so prominent, in consequence of a fall in the surface of the clay to the northwards, as previously alluded to; its place would be occupied by a thickening of the Ballast Beds, which we see towards the left hand of our section.

In this gravel, at a depth of 4 feet from the surface, several piles of oak were discovered in a vertical position, firmly imbedded in it. No remains of human work were found associated with them; they were, probably, the foundation piles of some old house.

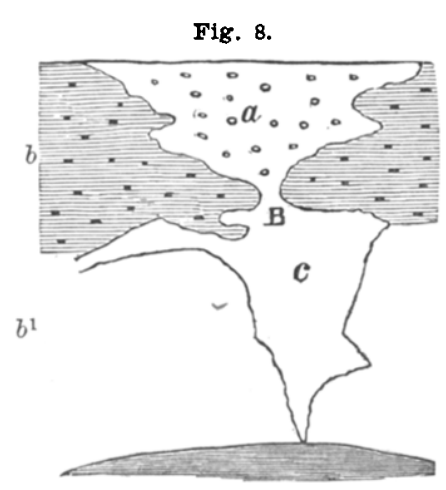

a. Whitey-brown Clay.

b. Gravels, \&c.

$b^{1}$. Ditto obscured.

c. Red Sandy Claj.

Fig. 8 represents one of the most puzzling sections displayed during the progress of the works. It is drawn through about 9 feet of the Ballast Beds, and rests upon the reddened portion of the London Clay. The brick rubbish had been removed. Its position is a little to the $\mathrm{W}$. of the preceding section. $a$ is a mass of whitey-brown clay, stuck all over with flints, like a plum pudding rather short of raisins, and thoroughly pervaded throughout its mass with a certain portion of the grits of the Ballast Beds. It is totally different in appearance and composition to any form of the London Clay, red or blue, occurring in this 
area; at $\mathbf{B}$ there is a sort of choke, where a reddish sandy clay, almost free from flint, is very closely encroached upon by the sands on either side. There then occurs a sort of expansion of the mass, into $c$, also a reddish sandy clay, which terminates in a thread, not a quarter of an inch thick, running down into the basement clay. For geological purposes, it would perhaps be idle to speculate on the causes of this appearance, which has verg likely an artificial origin.*

We have inserted this section principally to illustrate how easily an. error might occur in estimation by borings. So that other causes, besides mere carelessness or actual inaccuracy, do contribute to the uncertainty attendant upon these when within short distances of the surface. In another part of the works there is a regular dyke of this stuff, $66 \mathrm{ft}$. long by $8 \mathrm{ft}$, wide, at the broadest end. It must surely be artificial.

The fossils of the London Clay were not so numerous in this area as we expected, and most of them were very much pyritized. In many instances the clay had become so mineralized that it was impossible to assign them to any genus, much less to a species.

The following is the list of fossils obtained :-

Lamna elegans. $\boldsymbol{A} g$.

Goniaster Stokesii. Forbes.

Nautilus.

Triton Morrisii, Edw. M.S.

Pyrula Smithii. Sow.

Fusus bifasciatus. Sow. $"$ nitidus. Fudleston \& Price. " ap. (a cast.)

Cassidaris strista. Bow.

Pleurotoma stena. $E d w$. , varicosa. Hudleston and , helix.

Voluta Wetherellii. Sow.
Cypres oviformis. Sow.

Natica labellats. Lam.

Ceritbium Charlesworthii (?).

Aporrhais Sowerbyi. Mantell.

Dentalium anceps. Bow.

Solarinm patulum. Lam.

Arca impolits. Sonv.

Ancula papyracea. Sow.

Nucula Bowrerbankii. Sow. " ap.

Cryptodon angulatum. Sow. Goodhallii. Sow.

Syndosmya splendens. Sow.

Teredo antenauta. Sow.

Flint casts of Micraster cor-anguinum, Ananchytes, and Ventriculites were found in the gravels.

Besides the above, we found a fruit-stone, which was shown to Mr. Carruthers, F.R.S., of the British Museum, who stated that it appeared to him to be the stone of a Drupaceous fruit, and is un-

- Mr. Lett informs us that the saddle of clay had extended for some distance N.W. and S.E. It excited his indignation as being the most " useless. stuff he ever set eyes on ;" no good for brickmaking, no good for ballast, a dead loss, in fact, to the contractor. 
described by Bowerbank, and, as far as he knew, by any other author.

It will be well to bear in mind that the horizon is 300ft. below the top of the London Clay, as exhibited in the Highgate area, and this may account for so few fossils being discovered.

\section{Conclusiona.}

It only remains for us now to make some attempt to comparo these gravel beds with others in and about London.

For this purpose it may be well to bear in mind that the floor of the beds in the lower parts is abont 33 feet above Ordnance datum line (where unaffected by any great swelling), and about 44 feet above it in the upper part of the area, and that a bench of uncovered clay cuts them off on the south or towards the Thames.

The Ballast Beds belong to the great West London Block. This is bounded on the $\mathrm{S}$. by the tongue of London Clay, which is a continuation of that in the Serpentine valley, and more especially of that which occurs on the western escarpment of Campden Hill, and thence passes below the line of Piccadilly, and is, we believe, continued along the Strand, and possibly throngh Fleet Street, till it strikes the Fleet valley, which is the eastern boundary of the block. On the north its boundaries are not defined by any valley, the London Clay continuing to rise in this direction. The general plateau of this mass is between 80 and 90 feet above Ordnance datum; though at the N.W. extremity it rises much higher. Our area is on the S.E. slope of the block, and may bo described as belonging to the riparian portion of it. By the term " riparian," we mean that part of the sloping gravel sheet which is comprised between the often-mentioned bench of clay and the edge of the plateau, i. e., speaking roughly, between the $40 \mathrm{ft}$. and the $70 \mathrm{ft}$. line.* We have seen that in no place has the pure gravel a thickness of more than 13 feet, and if we add 6 feet for brick rubbish, the maximum of superficial deposit is 19 feet. This is exactly the depth given for similar deposits at Meux's brewery, which is about 85 feet above Ordnance datum, and may be con-

* It is worthy of remark in connection with this subject, that between these limits on the northern slope of the 'Thames Valley, the grivels bave as yet yielied no certain traces of Man, and but rare and doubtf nl indications of Post-glacial Mammals. The flint implements found recently by Col. Lane Fox at Acton (Quar. Journ. Geol. Soc., vol. xviii, p. 449) were mostly about the $80 \mathrm{ft}$. (slirface) line. The one at Grays' Inn would perhaps be about the $70 \mathrm{ft}$. line. On the other bund the rich finds of mammalian remains have been in the lower gravels and trick earths, the Mid Terrace Gravel of Whitaker and Fox. 
sidered as on the plateau. Smith's distillery at Covent Garden, nearly on the same level as the Law Courts, 25 feet. A well near Golden Square gives $10 \frac{1}{2}$ feet gravel, but does not state the amount of brick rubbish.

The following borings along the line of the Middle Level Sewer also belong to this part of the western block :-

\begin{tabular}{|c|c|c|}
\hline & Surface. & Ballast. \\
\hline n Fields & 8 & $11 \frac{1}{4}$ \\
\hline $\operatorname{Tar}$ & 13 & $1 \frac{1}{2}$ \\
\hline
\end{tabular}

Now we would wish to invite comparison between these very moderate thicknesses of gravel, as exhibited on the southward slope of the western block (where also the surface of the clay base is very irregular), and the much greater depths of gravel which obtain in the lower levels of the metropolitan area.

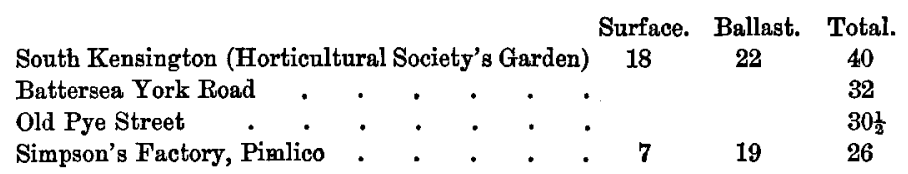

This latter is $13 \frac{1}{2}$ above Ordnance datum, hence the clay is reached at $12 \frac{1}{2}$ below that level.

These give us something like a mean of $20 \mathrm{ft}$. of gravels alone, being at least double of what we see in the western block of riparian and plateau gravels, and nearly three times the mean depth of the Law Courts gravels. Again there is a marked contrast in their position and mode of occurrence. In the recent excavations at Battersea (see paper by $\mathrm{Mr}$. John A. Coombs, page 33) we noticed on the whole a more even bedding, smaller size of flints, and certainly a less deeper stain from oxide of iron. This latter circumstance may partly arise from the immense quantity of water which those beds hold, the upper beds even being below high water mark of the adjacent Thames. In the very deep cutting on the Metropolitan District Railway, between Gloucester Road and Kensington High Street, the gravels are small, sandy, and cross-bedded.

In conclusion, we should endeavour to ascertain how far the present operations of the existing river in the immediate neighbourhood of London are producing effects similar to those we have attempted to describe.

The modern Thames has cut its way through the Lower Level 
Gravels down to the London Clay, but what is it doing by way of deposit? Let us take as a specimen the line of the embankment wall, now in course of construction along the north shore from Chelsea Bridge to the new Albert Bridge.

The excavation for the foundation of the wall runs along the edge of the beach at about the margin of ordinary low water. For a large portion of the distance there is not much more than 1 foot of extremely coarse gravel above the clay. Here and there occurs a pocket of some 3 feet of ballast, but this is an exception. A thin smear of "Battersea Butter" frequently just coats the surface. Here we have an appearance very similar to that which occurs at the S,E. corner of the Law Courts excavation, where circular pockets of red ballast have been mentioned as not unfrequent on the top of the clay bench so often alluded to. Indeed, the appearance is so similar as to suggest the probability of this clay bench representing the average low water line of the river or estuary of the period throughout a considerable lapse of time.

The excessive thinness of the river gravels along this line may be attributed to the wash of the tide at low water. A few yards further in the stream, where the cylinders of the Albert Bridge are being fixed, there is 4 feet of coarse ballast resting on 1 foot of fine ballast before the clay is reached. A section here (taking Trinity High Water Mark as the surface) gives-

$\left.\begin{array}{llllc}\text { Water } \ldots & \ldots & \ldots & \ldots & \text { 22ft. } 6 \text { in. } \\ \text { Coarse Gravel } & \ldots & \ldots & \ldots & \text { 4ft. } \\ \text { Fine Gravel } & \ldots & \ldots & \ldots & \text { 1ft. } \\ \text { London Clay } & \ldots & \ldots & \ldots & \end{array}\right\} \begin{gathered}\text { River Bed, Chelsea, } \\ \text { North shore. }\end{gathered}$

At the Cylinders on the south side we have a greater deposit.

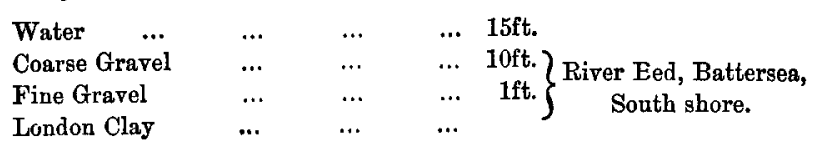

In the distance, between the two sets of cylinders $(=$ to rather more than half the width of the Thames), a slight rise of the surface of the London Clay towards the south is established. It would seem to be about 1 foot.

Proceeding from low water mark in an opposite direction, i. e., away from the centre of the river, we also find the modern deposits thickening to the depth of several feet until they finally mix with the finer and more sandy beds of the Lower Level Gravels. At a distance of about 120 feet from low water mark, this beach 
deposit of the existing Thames, mixed, probably, with a portion of the older beds, attains a depth of 17 feet, if not more, of which $5 \frac{1}{2}$ feet is black and contaminated, and $11 \frac{1}{2}$ feet red gravels and sands, containing remains of small oxen and of red deer in considerable abundance.

Taking another part of the river nearer our area, we find at Westminster Bridge (on the authority of Mr. Bryant) that there is about 3 feet of coarse ballast in the centre, with from 7 feet to 10 feet along the north shore. At Blackfriars, about 3 feet in the centre, and just opposite the entrance of the Fleet; we have 12 feet of ballast resting on an accumulation of silty mud.

This latter circumstance tends to show that in certain bights of the river a considerable depth of ballast may even now be accumu. lated under favourable conditions, though the general deposit of the modern Thames bed is scanty where the current is strong. The quality is certainly coarse, and the fragments larger than those of the Lower Level Gravels through which the bed is cut. This may be the result of a stronger sweep of tide through narrowing of the channel. In the Law Courts area, where the gravels belong, we presume, to the riparian portion of the Upper Level Gravels, the fragments, as before noticed, run larger than in the lower beds, and, in this respect, more nearly resemble the ever-shifting deposits of the modern Thames.

\section{Description of New Species.}

1. Pledrotoma varicosa. - This Mr. Etheridge, F.R.S., considered new to Britain. It was very numerous in the deepest parts of the excavations. Shell elongato-fusiform, whorls five, convex, transversely striated, having varicose longitudinal costæ, which gradually fade away on the body whorl before reaching the canal, aperture ovate. This shell we name provisionally, as it may have been figured by foreign authors.

2. Fusus nitidus.-This specimen was shown to $\mathrm{Mr}$. Etheridge, F.R.S., who pronounced it to be probably new to England, and also probably figured, but not yet named by Mr. Edwards. We only obtained one specimen of this fossil. Description-Shell oratofusiform, transversely striated, whorls five, convex, sutures distinct, aperture ovate. This we also propose to name provisionally, $i, e$, subject to its not having been named by any foreign palæontologist. 
Proc. Geol Assoc: Vol. III PI. II.

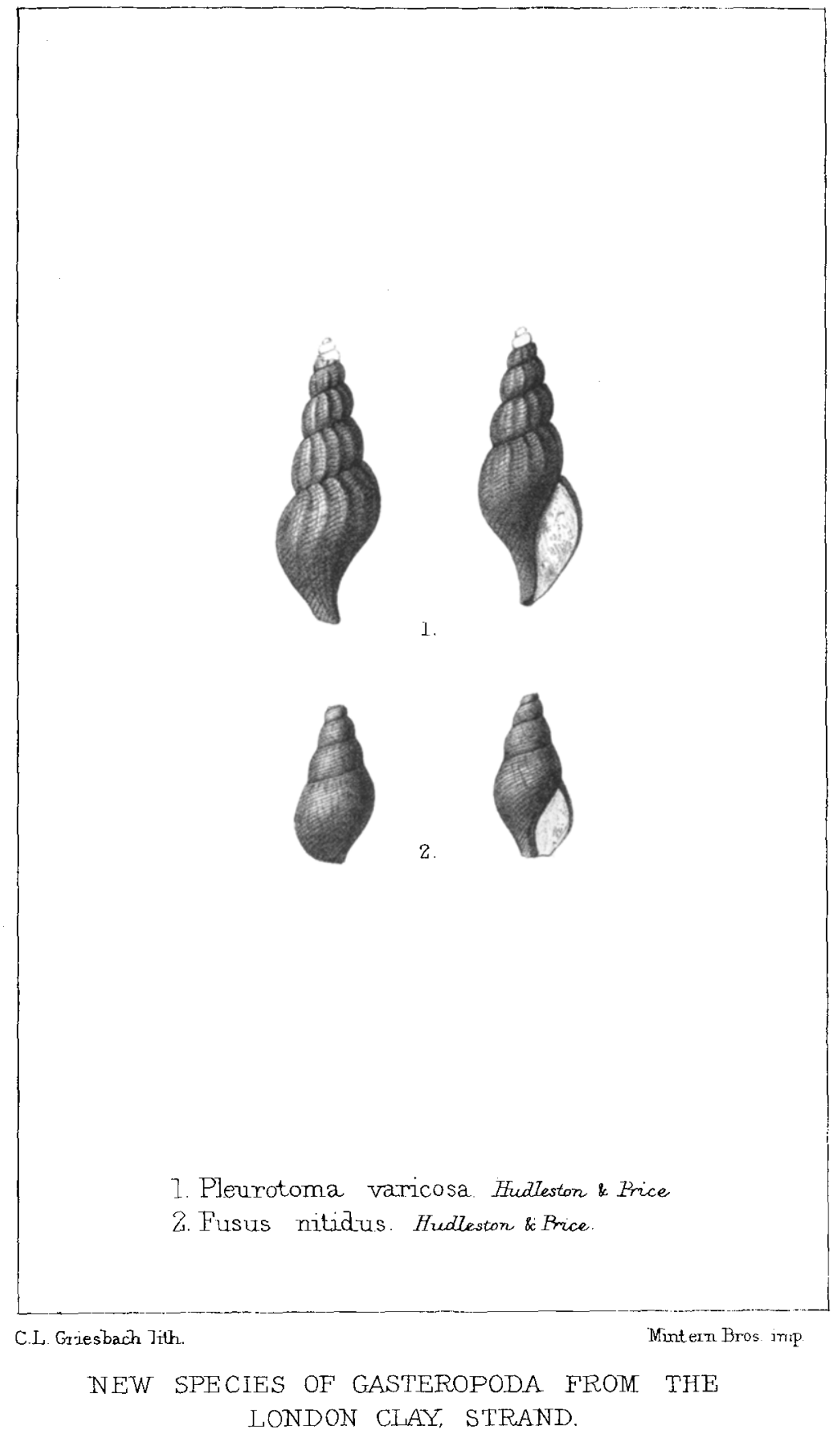

